\title{
DINAMIKA EPISTEMOLOGI FIKIH: Studi terhadap Beberapa Kecenderungan Usul Fikih Kontemporer
}

\author{
Agus Sunaryo \\ STAIN Purwokerto \\ Jl. Jend. Ahmad Yani No. 40 A Purwokerto \\ Email: denbagoes_28@yahoo.co.id
}

\begin{abstract}
Abstrak
Cara pandang keagamaan seorang muslim, sangat ditentukan oleh bagaimana mereka membangun keyakinan dan pemikirannya tentang kehendak Tuhan yang tertulis dalam teks-teks suci keagamaan. Sifat teks-teks tersebut yang diam dan berjarak dengan para pembaca, telah melahirkan sikap keagamaan yang berbeda-beda antara satu muslim dengan muslim lainnya. Sehingga, di antara mereka ada yang memiliki cara pandang dan sikap keagamaan terbuka serta toleran, selain tentu saja ada yang memiliki sikap dan cara pandang keagamaan eksklusif-puritan. Masing-masing dari kelompok ini tampil ke permukaan menjadi penafsir dari teks-teks keagamaan dan sekaligus mempromosikan diri sebagai yang paling otoritatif dalam melakukan penafsiran. Artikel ini akan membahas bagaimana dua kecenderungan ini bisa berkembang dan mewarnai diskursus keislaman, khususnya di era kontemporer.
\end{abstract}

Kata Kunci: epistemologi, utilitarianisme, liberal, puritan, teks, konteks

\begin{abstract}
Religious perspective among Muslims is very determined by how they establish their belief and thought about God's wish written on holly texts. The silent and separating characteristic of the texts between readers has born many religious attitudes between one Muslim and the others. It's very possible that one of them may have inclusive perspective and tolerance in religious attitude. And it's also possible that some of them have exclusive perspectives as a contrary. Each of this group of perspectives shows to the public as interpreters of the religious texts and at the same time they promote themselves as the most authoritative interpreters. This article analizes how both of preferences can grow up and put a colour to Islamic discourses, especially in contemporary era.
\end{abstract}

Keywords: episthemology, utilitarianism, liberal, puritan, text, context

\section{A. Pendahuluan}

Diakui atau tidak, perubahan secara besar-besaran yang terjadi pada kehidupan umat manusia di abad modern, telah membawa pengaruh pada munculnya pola pikir dan cara pandang keagamaan (religious worldview) baru baik di lingkungan umat Islam maupun di agama lain. ${ }^{1}$
Dalam Islam, persoalan cara pandang keagamaan bukanlah merupakan hal asing dan bahkan telah melahirkan banyak sekali aliran berfikir (mazhab) yang secara ideal sering dipahami sebagai sebuah keniscayaan beragama serta dipercaya sebagai salah satu bentuk kasih sayang Tuhan kepada hambaNya. Sebuah adagium yang banyak dinisbatkan kepada 
nabi menyebutkan bahwa Nabi pernah bersabda: perbedaan (pendapat) di kalangan umatku adalah rahmat. ${ }^{2}$ Meskipun hadis ini diragukan keasliannya dari Nabi, namun banyak ulama' yang mengambil spirit keagamaan dari pernyataan tersebut, terutama ketika menyikapi persoalan perbedaan cara pandang dalam beragama. Imam alNasafi misalnya, dalam salah satu kitabnya pernah mengatakan: pendapat kami adalah benar namun mengandung kemungkinan untuk salah. Sedangkan pendapat orang lain adalah salah (menurut kami), namun mengandung kemungkinan untuk benar. ${ }^{3}$

Perbedaan, dalam bentuk apapun, sebenarnya bukanlah persoalan yang perlu dikhawatirkan. Namun ketika perbedaan tersebut telah mengarah pada terbentuknya hegemoni wacana, klaim kebenaran serta intoleransi dalam menyikapi kelompok yang berbeda, maka hal ini perlu mendapatkan perhatian serius. ${ }^{4}$

Sebagai diskursus yang secara lughawi memiliki makna "pemahaman", maka perbedaan pendapat di dalam fikih, tidak lain merupakan konsekuensi logis atas kerja berfikir manusia, ${ }^{5}$ khususnya ketika dihadapkan pada persoalanpersoalan yang dikategorikan sebagai furü'iyyah-ijtihādiyyah. Oleh karenanya sangat wajar jika dalam perkembangannya fikih, dari dahulu hingga sekarang, selalu diwarnai dengan perbedaan pendapat dan lahirnya aliranaliran (mazāhib). Di periode sahabat, muncul aliran yang disebut dengan ahl alhadis dan ahl al-ra'y. Aliran ahl al-hadis berpusat di Madinah, sementara ahl al$r a$ 'y berpusat di Kuffah. ${ }^{6}$

Di era empat mazhab, muncul karakter berfikir yang juga sangat berbeda antara mazhab Malikiyyah (Imam Mālik ibn Anas) dan Hanafiyyah (Abū Hanifah). Para ahli mengkategorikan Mazhab Malikiyyah sebagai penerus ahli al-hadis, sementara Hanafiyyah adalah penerus ahli al-ra'y pada masa sahabat. Adapun Imam alSyāfi'i dianggap telah menghadirkan pemikiran yang menjembatani kesenjangan antara Malikiyyah dan Hanafiyyah. Sehingga mazhab Syafi'iyyah secara metodologis mencoba menggabungkan antara penggunaan hadis disatu sisi dan pemanfaatan nalar di lain sisi. Kedua perangkat metodologis ini selalu digunakan secara proporsional dalam upaya menggali hukum Islam yang moderat. $^{7}$

Sampai disini perbedaan pendapat dikalangan ulama' fikih masih berada dalam lingkup idealnya. Namun seiring perkembangan zaman, perbedaan yang terjadi kemudian melahirkan tiga paradigma besar dalam fikih yang mendominasi perkembangan diskursus fikih di zaman modern dan seringkali harus berebut kuasa dalam memahami makna ayat-ayat Tuhan. Penulis menyebut ketiganya dengan paradigma fikih utilitarianisme, fikih liberal, dan fikih eksklusif-puritan.

Paradigma yang pertama menawarkan cara pandang fikih yang terbuka namun tidak keluar dari frame dominan ulama fikih. Metodologi yang mereka kembangkan juga memiliki akar akademik yang kuat dengan ulama' mayoritas yang hidup sebelum mereka. Diantara tokoh yang bisa dijadikan representasi dari paradigma ini antara lain, Yūsuf al-Qarḍ̄wìi, Wahbah alZuhayli, AҐi Jum'ah, A $\bar{i}$ al-Ṣābūnì dan Sa’ìd Ramaḍān al-Būṭì.

Adapun paradigma yang kedua (liberal) lebih banyak dinisbatkan kepada tokoh-tokoh seperti Hasan al-Turabi, Nasr Hamid Abu Zayd, Mahmud Muhammad Thaha, Abdullah Ahmen alNaim, Fazlur Rahman, Muhammad Syahrur, Fatimma Mernisi, Mohammed Arkoun, Hasan Hanafi, Abed al-Jabiri dan yang lainnya. Sedangkan paradigma yang terakhir (eksklusif-puritan) bisa direpresentasikan oleh pemikiran tokohtokoh Ikhwanul Muslimin (Hasan alBannā, Sayyid Muhammah Qutb dan 
Abū al-A'lā al-Maudūdi), ${ }^{8}$ Muhammad ibn Abd al-Wahhāb, Syaikh Abdullāh ibn Bāz, Ibn Utsaimin, Nașirudin al-Albāni dan Ibn Fauzan. ${ }^{9}$

Sementara paradigma eksklusifpuritan, lebih banyak diikuti oleh kelompok-kelompok yang secara geneologis mengikuti cara berfikir organisasi ikhwanul muslimin, wahabi atau organisasi-organisasi lain yang mengusung semangat anti Amerika, zionisme dan menawarkan konsep alrujū' ilā al-kitāb wa al-sunnah dan terobsesi untuk mendirikan khiläfah islämiyyah.

Ketiga paradigma fikih di atas adalah yang paling dominan di zaman sekarang. Masing-masing seolah berebut simpati umat untuk bisa diterima sebagai jalan menuju keselamatan. Atas dasar itu pula, penulis tertarik untuk melakukan suatu kajian ilmiah tentang bagaimana ketiga paradigma di atas muncul dan berkembang. Dari kajian ini diharapkan bisa ditarik suatu benang merah mengenai titik singgung antar paradigma dan kemungkinan untuk mencari titik temu di antara mereka.

\section{B. Tipologi Epistemologi Fikih}

1. Fikih Utilitarianisme

Dialektika antara fikih dengan modernitas telah melahirkan banyak tokoh yang hasil ijtihadnya dianggap mewakili semangat zaman (modern). Di antara mereka ada Muhammad Abduh (w. $1323 \mathrm{H}$ ), Jamal ad-Din al-Afghani (w. 1314 H) dan Muhammad Rasyid Ridha (w. $1354 \mathrm{H}$ ). Ketiga tokoh ini, meskipun lebih dikenal sebagai mufassir dan pendidik (bukan fuqaha'), namun pemikirannya telah mampu mendobrak kebekuan yang sebelumnya menyelimuti alam pikir umat Islam. Melalui konsepkonsep mereka, segregasi antara Islam dan modernitas mulai sedikit terurai.

Beralihnya fase modern menjadi post modern, nampaknya juga melahirkan perspektif baru dalam diskursus keislaman. Abduh dan tokoh-tokoh yang seangkatan dengannya dianggap mewakili rasionalisme dan modernisme Islam. Mereka telah berhasil membangun paradigma baru diskursus keislaman dari yang sebelumnya kering, eksklusif, jumud dan tekstual, menjadi lebih hidup, berani, terbuka (inklusif) dan rasional. Namun demikian, modernisme dengan karakter "holisme" nya dianggap kurang berhasil menjawab problem pluralitas masyarakat modern, bahkan pluralitas dalam diskursus keislaman.

Berbekal disiplin keilmuan fikih yang mumpuni, tokoh-tokoh seperti Abdul Wahhab Khallaf, Mahmud Syaltut, Yusuf al-Qarḍāwī, Sa'id Ramaḍan alBūṭi, Ali Jumah, Ali al-Ṣābūnì dan Wahbah al-Zuhayli, muncul kepermukaan seolah ingin bersaing dengan para tokoh lainnya dalam membangun paradigma fikih baru. Berbeda dengan Abduh dan kawankawan, tokoh-tokoh ini mencoba menawarkan perspektif Islam yang lebih terbuka, elastis dan dinamis melalui jendela fikih. Fikih yang sebelumnya terkunci dalam mazhab-mazhab baku (mazhab empat), terurai dengan model penalaran serta penyajian muqāran (komparasi). Kajian dan pembahasan fikih tidak lagi terkurung dalam satu mazhab tertentu melainkan diperkaya dengan uraian lintas mazhab. Dari sini pembaca didewasakan dan dicerahkan alam pikirnya dengan kemungkinan untuk memilih satu diantara mazhabmazhab fikih yang dikaji. Model fikih manhaji (metodologis) juga dikembangkan sedemikian rupa untuk menutup kekurangan yang ada dalam model fikih qawli. Buktinya, pada era mereka kitab-kitab usul fikih seolah menemukan momentum kematangannya. Banyak sekali kitab usul fikih yang lahir sebagai imbangan dari kitab-kitab fikih yang mereka susun, baik yang mengikuti sistematika ulama-ulama sebelumnya atau kajian-kajian yang lebih tematik. ${ }^{10}$

Problem mendasar yang dihadapi hukum Islam di abad modern adalah 
tingkat kecakapannya dalam merespon semangat zaman. Dalam hal ini, zaman modern sudah tentu menawarkan kompleksitas yang lebih rigid dan beragam. Sementara itu, hukum Islam harus berada di antara dua kutub, modernitas dan teks-teks suci yang turun berabad-abad lampau.

Untuk menyikapi kondisi seperti ini, diperlukan perspektif baru yang mampu meletakkan fikih benar-benar sebagai produk budaya atau hasil dari dari sebuah dialektika dinamis antara teks dan konteks (modernitas). Salah satu yang patut dicermati adalah ide yang ditawarkan oleh Yūsūf al-Qarḍāwì mengenai perlunya melakukan reformasi fikih. Al-Qarḍ̄āi mengusulkan agar fikih dapat diperbaharui menjadi fikih realitas (fiqh al-wäqi') dan fikih prioritas (fiqh alawlāwiyāt). Dengan keduanya, fikih diharapkan mampu menjadi pedoman baru bagi problem-problem kemanusiaan yang muncul di tengah masyarakat. Tidak hanya persoalan yang berdimensi vertikal (ta'abbudi), melainkan juga persoalan kemanusiaan seperti isu kesetaraan gender (fiqh al-mar'ah), ketatanegaraan (fiqh al-dawlah), kewarganegaraan (fiqh al-muwàtanah) dan lain sebagainya. ${ }^{11}$

Dengan semangat yang sama, para ulama kontemporer juga berusaha mengembangkan sebuah metodologi baru agar fikih bisa menjadi pintu gerbang terciptanya kemaslahatan hidup bagi masyarakat. Dalam konteks ini, fikih dijadikan sebagai sebagai sumber kemaslahatan yang tidak hanya milik penguasa ataupun Tuhan, melainkan kemaslahatan yang bisa dirasakan oleh seluruh umat manusia di muka bumi ini.

Paradigma fikih sebagai sumber kemaslahatan (biasa juga disebut fiqh almaqāsid) sebenarnya bukan hal baru dalam diskursus keislaman. Namun demikian, paradigma ini seperti menemukan momentumnya di masa sekarang, khusunya ketika fikih dihadapkan pada serangkaian persoalan yang sama sekali baru dan membutuhkan ijtihad kreatif dari para ahli fikih.

Sebelum

fiqh al-maqāsid

dikembangkan, paradigma fikih sebelumnya didominasi oleh cara pandang literalistik baik dari kalangan mutakallimin (Syafi'iyyah, Malikiyyah, Hanabilah dan Mu'tazilah) atau dari kalangan Hanafiyyah. Kelompok mutakallimin yang lebih bercorak teologis-deduktif dan kelompok Hanafiyyah yang bercorak induktifanalitis, sama-sama manjadikan teks sebagai poros pijak kajiannya. Meminjam istilah Abed al-Jabiri, corak pemikiran inilah yang kemudian disebut dengan epistemologi burhani. ${ }^{12}$ Sebuah epistemologi yang memusatkan kajian dan analisisnya pada teks-teks keagamaan.

Dominasi epistemologi burhani berlangsung kurang lebih lima abad (dari abad ke-2 $\mathrm{H}$ hingga abad ke-7 H), sampai kemudian muncul tokoh al-Syatibi (w. $790 \mathrm{H} / 1388 \mathrm{M}$ ) yang mengembangkan kajian di balik teks (ma haula an-nașs). Bagi al-Syatibi, kajian hukum Islam akan menemukan jatidirinya yang selaras dengan semangat dan tuntutan zaman apabila tidak melulu dipenjara pada teksteks agama, melainkan ia bisa digali dari pesan (maksud) Tuhan yang paling mendasar sebagai Syari' atau yang biasa di kenal dengan maqāsid al-syarìah. Sampai pada titik ini, as-Syatibi sebenarnya belum melakukan apa yang disebut oleh Thomas Kuhn sebagai pergeseran paradigma (paradigm shift). ${ }^{13}$ Ia tidak lebih hanya melengkapi dari apa yang kurang dari paradigma literalistik dan belum melakukan perubahan yang revolusioner.

Beberapa abad setelah era alSyatibi, muncul para pembaharu yang mencoba merevitalisasi teori maqāsid alsyari' 'ah. Sebut saja misalnya Muhammad Abduh (w. 1905 M), Rasyid Rida (w. $1935 \mathrm{M}$ ), Abdul Wahhab Khallaf (w. 1956 M), 'Allal al-Fasi (w. 1973 M) atau Hasan Turabi. Menurut Wael B. Hallaq 
mereka ini dikenal dengan pengusung aliran utilitarianisme keagamaan, dimana pemikiran keagamaannya menitik beratkan pada teori bahwa maksud Tuhan menetapkan syariat adalah untuk merealisasikan kemaslahatan. ${ }^{14}$

\section{Fikih Liberal}

Keberadaan fikih yang dilematis, yaitu antara teks yang berorientasi pada masa lampau dan konteks yang berumpu pada masa kekinian, sepertinya belum mampu diurai secara meyakinkan oleh kelompok utilitarianisme. Hal ini kemudian memicu semangat tokoh-tokoh seperti, Fazlur Rahman, an-Na'im, Syahrur dan yang lain, untuk melakukan perubahan paradigma terkait dengan pengembangan kajian keislaman, khsusnya hukum Islam. Atas dasar ini pula Wael B. Hallaq mengkategorikan mereka sebagai pengusung aliran liberalisme keagamaan (religious liberalism). Karakter liberal dari kelompok ini nampak dari tawarantawaran metodologisnya yang cenderung keluar dari frame epistemologi fikih sebelumnya $^{15}$, baik yang literalistik maupun yang utilitarianistik. Untuk melihat bagaimana epistemologi liberal ini dibangun, berikut akan diuraikan pemikiran dari tiga tokoh pengusung aliran liberalisme keagamaan, yaitu Fazlurrahman, an-Na'im dan Muhammad Syahrur.

\section{a. Fazlur Rahman}

Berbicara tentang alur pemikiran Rahman ada dua istilah metodik yang sering disebutkan dalam buku-bukunya yakni historico-critical method (metode kritik sejarah) dan hermeunetic method (metode hermeunetik). Kedua istilah tersebut merupakan kata kunci untuk menelusuri metode-metode dalam pemikirannya. ${ }^{16}$

Dalam memahami dan menafsirkan sumber utama Islam, dalam hal ini al-Qur'an, Rahman menggunakan teori doble movement (gerak ganda). Hubungan yang dialektis antara dua unsur yang terdapat dalam alqur'an yaitu wahyu ketuhanan yang suci di satu sisi dan sebagai sejarah kemanusian yang profane disisi yang lain. Dua Unsur inilah yang menjadi tema sentral metode Rahman.

Permasalahannya ada pada bagaiman cara mendialogkan antara dua sisi tersebut agar nilai-nilai kewahyuan bisa selalu sejalan dengan sejarah umat manusia. Gerak pertama pada teori Rahman menghendaki adanya memahami makna al-Quran dalam konteks kesejarahannya baik secara spesifik dimana kejadian itu berlangsung (mikro) maupun secara global bagaimana kondisi sekitar kejadian itu pada umumnya (makro). Dari sini bisa diambil pemahaman yang utuh tentang konteks normatif dan historisnya suatu ayat yang kemudian memunculkan istilah legal specific (praktis temporal) dan moral idea (normatif universal). Kemudian, gerak kedua yang dilaklukan adalah upaya untuk menerapkan prinsip dan nilai-nilai sistematik dan umum dalam konteks penafsiran pada era kontemporer yang tentunya mensyaratkan sebuah pemahaman yang kompleks terhadap suatu permasalahan. Disini terlihat keberanjakan Rahman dari metodologi ushul fikih lama yang cenderung literalistik dan menurutnya perlunya penguasaan ilmu-ilmu bantu yang bersifat kealaman maupun humaniora agar para penafsir terhindar dari pemahaman yang salah. ${ }^{17}$

Konstruksi bangunan pemikiran Rahman tentang hermeneutika al-Qur'an dengan teori double movement nya adalah merupakan respons terhadap model penafsiran dan pemahaman al-Qur'an yang bersifat "atomistik" dan sepotongpotong dalam memahami teks al-Qur'an sebagaimana dikembangkan oleh mufassir abad pertengahan dan beberapa mufassir tradisional era kontemporer. ${ }^{18}$ Pendekatan model ini jelas mengecilkan koherensi dan kesatuan yang selalu di garisbawahi oleh pesan-pesan wahyu dan menghalang-halangi upaya perumusan 
pandangan hidup al-Qur'an (Qur'anic Weltanschauung) secara menyeluruh dengan menggunakan kosa kata alQur'an itu sendiri.

Menurut Rahman, tanpa memahami pandangan hidup al-Qur'an, para penafsir modern tidak akan mampu membedakan konteks sosial, tatacara, norma dan adat istiadat masa lalu yang dicangkokkan dan dilengketkan sedemikian rupa oleh penafsir pada karya-karya tafsir mereka terhadap wahyu yang asli. Atas dasar inilah Hermeneutika Rahman selalu konsern pada pemahaman tentang fakta-fakta sejarah dari wahyu berikut nilai-nilai yang melingkupinya. Ide pokok dari hermenutika ini adalah keinginan Rahman untuk melakukan interpretasi terhadap nilai (value). Menurutnya, nilai, yang benar-benar layak disebut moral, juga memiliki aspek-aspek ekstra historis, "trancendental being", dan penerapan atau pelaksanaanya pada penggal sejarah tertentu (klasik, tengah, modern atau pasca modern) tidak dapat menuntaskan penerapan secara utuh maknanya yang terdalam. ${ }^{19}$ Dengan demikian, kebutuhan untuk menerapkan wahyu pada konteks masyarakat kenabian adalah hal yang tidak bisa ditawar.

Dalam upaya menjelaskan bagaimana cara tradisi intelektual muncul kepermukaan dan berkembang dalam sejarah, Rahman menjelaskan bahwa hubungan antara tradisi (kebenaran yang diwahyukan) dan sejarah tetap merupakan tantangan terhadap pemahaman kita mengenai tradisi intelektual. Ada kebutuhan mendesak untuk menjelaskan gerak tradisi, yakni hukum gerak yang berlangsung di dalamnya dan bagian-bagian dinamisnya. Terkait dengan hal ini Rahman menegaskan perlunya mengembangkan, memperbaiki dan menyempurnakan ilmu pengetetahuan keislaman (Islamic studies) kita seperti teologi, fikih, filsafat dan sufisme. Urgensi dari ilmu-ilmu ini tidak lain adalah untuk menjelaskan ada tidaknya kesinambungan dari tradisi itu sendiri. Dengan kajian sejarah memungkinkan kita untuk memahami bagaimana ide-ide atau buah pikiran tersebut bermula dan peran apa yang dimainkan dalam proses pembentukan tradisi intelektual. Secara sederhana Rahman membuat ilustrasi dengan mengatakan bahwa sebagai tradisi keagamaan, Islam telah dibangun oleh generasi terdahulu. Untuk itu, Rahman menolak keras orang-orang muslim yang menjadikan dan mempertahankan masa lalu seolah-oleh manjadi Tuhan bagi masa dan generasi sesudahnya. Ia juga tidak sependapat dengan anggapan bahwa ulama generasi terdahulu tidak mungkin ditandingi oleh ulama atau pemikir generasi sekarang dalam semua aspeknya.

b. Abdullah Ahmed al-Na'im An-Naim Menawarkan metodologi alternatif dalam menguak pandangan Islam terhadap Hak Asasi Manusia (HAM). Sejak awal an-Na'im memang memiliki concern terhadap hukum Islam dalam kaitannya dengan isu-isu internasional modern seperti HAM, konstitusionalisme modern, dan hukum pidana modern. Menurutnya hukum Islam pada saat ini membutuhkan reformasi yang dalam terminologinya disebut "dekontruksi".

Metode pembaharuan hukum Islam al-Na'im sebenarnya berangkat dari metodologi yang diintroduksi dari gurunya sendiri, Mahmoud Muhammad Thaha yakni teori evolusi yang memuat teori naskh (sebagaimana dikenal dalam usul fikih) namun substansi dalam penerapannya berbeda. Dalam pandangan Thaha, teori Naskh lama yang menganggap bahwa ayat-ayat (juga hadis) Madaniyah menghapus ayat (juga hadis) Makkiyah, harus dibalik, yakni ayat makkiyah lah yang justru menghapus ayat madaniyyah. Keyakinan Thaha bahwa pada abad modern ini ayatayat makiyah justru menasakh ayat-ayat madaniyah, karena ayat-ayat makkiyah 
bersifat lebih universal dan abadi. Ia menganjurkan kebebasan, persamaan derajat da tidak berprilaku diskriminatif, baik atas alasan jender, agama maupun kepercayaan. ${ }^{20}$

Dari kerangka berpikir sang guru inilah an-Na'im memformulasikan buah pikirannya terhadap isu-isu global yang menjadi minat kajiannya. Menurut anNa'im pilihan Thaha terhadap abad ke-20 sebagai abad yang tepat untuk pemberlakuan kembali ayat-ayat Makiyah memang subjektif, meski dikemukakan secara rasional. Namun, bagaimanapun menurut an-Na'im kita tidak memiliki alternatif ide yang lain untuk menggantikan pemikiran Thaha itu. Dengan kata lain, an-Na'im ingin mnyatakan bahwa metodologi Thaha merupakan keniscayaan zaman. Umat Islam dihadapkan kepada dua pilihan yang tidak relevan khususnya dalam bidang hukum publik. Pertama, tetap menggunakan piranti hukum klasik dengan berbagai macam kekurangan dan kerancuan terminologisnya, dan yang kedua, menggunakan hukum barat yang disebarkan melalui kolonialisme yang mau tidak mau harus diterima karena tidak ada alternatif yang memadai. ${ }^{21}$

Meskipun piranti metodologis alNaim lebih diproyeksikan pada bidang hukum publik namun secara paradigmatik bisa saja diterapkan dalam bidang hukum privat pada umumnya dan hukum keluarga pada khususnya. Hal ini mengingat bahwa kegelisahan hukum Islam adalah sama yaitu bagaimana keberadaannya tetap relevan dalam perkembangan zaman.

c. Muhammad Syahrur

Secara umum pemikiran Syahrur tertuang dalam beberapa karya, di antaranya yang paling monomental adalah al-Kitāb wa al-Qur'ān: Qirā'ah Mu'assirah. ${ }^{22}$ Kitab tersebut merupakan hasil perjalanan panjang intelektualnya selama kurang lebih 20 tahun. Dalam buku ini Syahrur melakukan pembacaan ulang terhadap Islam yang kemudian mampu menghasilkan pemahaman dan kesan kuat tentang akurasi istilah-istilah yang digunakan dalam al-Kitab (alQur'an).

Secara umum, Syahrur merumuskan metode berfikirnya ke dalam beberapa poin, yaitu: pertama, permasalahan mendasar dalam filsafat adalah persoalan hubungan antara kesadaran akal (ide) dan materi (wujud kongkret). Menurutnya sumber pengetahuan manusia adalah alam materi yang berada di luar diri manusia. Ini berarti pengetahuan yang sesungguhnya bukanlah semata-mata bentuk pikiran, melainkan sesuatu yang terdapat padanannya di alam realitas-empiris. $K e d u a$, bertolak dari pandangan bahwa pengetahuan manusia berasal dari luar dirinya tersebut, ia menawarkan filsafat Islam modern yang didasarkan atas pengetahuan akal yang bertolak dari halhal yang kongkrit yang dapat dicapai oleh indera manusia terutama pendengaran dan penglihatan untuk mencapai pengetahuan teoritis yang murni (benar). Ia juga menyerukan penolakan terhadap pengetahuan yang di dasarkan pada ilham (al-isyrāqiyyah al-ilāhiyyah) yang hanya dimiliki oleh ahli mukāsyafah (sufi). ${ }^{23}$

Ketiga, pemikiran manusia mulamula berupa pemikiran yang terbatas pada apa yang dapat ditangkap oleh pendengaran dan penglihatan saja, kemudian meningkat hingga mencapai pemikiran murni yang bersifat umum. Oleh karenanya, alam nyata merupakan permulaan bagi alam materi yang dapat dikenal oleh indera manusia. Pengetahuan manusia akan terus berkembang hingga mencapai hal-hal yang hanya dapat ditangkap oleh akal. Manurut Syahrur, alam nyata dan alam ghaib sama-sama merupakan materi. Perkembangan ilmu pengetahuan hingga saat ini baru mampu menggapai alam kongkrit dan nyata, pada waktunya nanti ia akan terus berkembang sehingga mampu mencapai hal-hal yang ghaib. Keempat, ia berpendapat bahwa alam 
diciptakan dari materi, bukan dari ketiadaan. Hanya saja sifat materi tersebut berbeda dengan yang ada sekarang. Suatu saat nanti ia juga akan diganti dengan materi yang berbeda pula, yakni alam lain yang disebut dengan akhirat. Kelima, tidak ada pertentangan antara al-Qur'an dan filsafat yang merupakan induk dari ilmu pengetahuan. $^{24}$

Dengan pembacaan ulangnya ini ia juga berhasil merumuskan sebuah terori yang cukup tekenal yaitu "teori batas" (nazariyyah al-hudūd). Syahrur memandang adanya dua sifat pokok yang terdapat dalam al-Qur'an yang mutlak harus dimengerti untuk bisa memahami keistimewaan agama Islam, yakni hanifiyyah dan istiqāmah. Kedua sifat ini selalu bertentangan tetapi saling melengkapi. Berdasarkan sejumlah ayat Syahrur menyimpulkan bahwa makna hanafiyah adalah penyimpangan dari sebuah garis lurus, sedangkan istiqamah merupakan sifat atau kualitas dari garis lurus itu sendiri atau yang mengikutinya. Hanifiyyah adalah sifat alam yang juga terdapat dalam sifat alamiah manusia.

Syahrur berargumen dengan dalil fisikanya bahwa tidak ada benda yang selalu bergerak dalam bentuk garis lurus. Seluruh benda sejak dari elektron yang paling kecil hingga galaksi yang terbesar bergerak secara hanifiyyah (tidak lurus). Oleh karena itu ketika manusia dapat mengusung sifat seperti ini maka ia akan dapat hidup harmonis dengan alam semesta. Demikian halnya kandungan hanifiyyah dalam hukum Islam yang cenderung selalu mengikuti kebutuhan sebagian anggota masyarakat dengan penyesuaian dengan tradisi masyarakat.

Untuk mengontrol perubahanperubahan ini maka adanya sebuah garis lurus istiqamah menjadi keharuasan untuk mempertahankan aturan-aturan hukum yang dalam konteks inilah teori batas diformulasikan. Garis lurus bukanlah sifat alam ia lebih merupakan karunia Tuhan agar ada bersama-sama dengan hanifiyah untuk mengatur masyarakat. ${ }^{25}$

Berdasarkan kajiannya terhadap ayat-ayat hukum, Syahrur menyimpulkan adanya enam bentuk dalam teori batas. Pertama, ketentuan hukum yang memiliki batas bawah. Ini terjadi dalam hal macam-macam perempuan yang tidak boleh dinikahi. Kedua, ketentuan hukum yang hanya memiliki batas atas. Ini terjadi pada tindak pidana pencurian. Ketiga, ketentuan hukum yang memiliki batas atas dan bawah, seperti hukum waris dan poligami. Keempat, ketentuan hukum yang mana batas bawah dan atas berada pada satu titik (garis lurus) tidak boleh lebih dan kurang, ini terjadi pada hukuman zina yaitu 100 kali jilid. Kelima, ketentuan yang memiliki batas atas dan bawah tetapi kedua batas tersebut tidak boleh disentuh, karena dengan menyentuhnya berarti telah terjatuh pada larangan Tuhan, hal ini berlaku pada hubungan pergaulan antara laki-laki dan perempuan Keenam, ketentuan hukum yang memiliki batas atas dan bawah dimana batas atasnya tidak boleh dilampaui dan batas bawahnya boleh dilampaui. Batas atas terjadi pada riba dan batas bawah adalah pinjaman tanpa bunga (al-qard alhasan). $^{26}$

3. Fikih Eksklusif-Puritan

Sejak abad ke-7 M, fikih telah berada pada puncak kesakralan. Orientasi umat selalu merujuk kepada fiqh sebagai justifikasi keselamatan dan kesesatan. Sebagai sebuah rujukan hukum, fiqh tampak subjektif: hitam-putih, benarsalah, dan halal-haram. ${ }^{27}$ Bahkan, di tangan beberapa orang, fikih dapat berubah menjadi tata aturan yang otoriter, tidak ramah dan kebal pembaruan. Dengan kalimat lain, fikih selalu menampilkan dua wajah, moderatisme di satu sisi dan puritanisme di lain sisi. ${ }^{28}$

Gerakan menjaga otoritas fikih yang cukup massif, misalnya dengan memunculkan "kampanye" tertutupnya pintu ijtihad, jelas mengorientasikan umat 
untuk senantiasa tunduk kepada produk pemahaman keagamaan puluhan abad silam dan menisbikan hentakan gelombang zaman. ${ }^{29}$ Jika di era yang lalu teks-teks hukum produk ulama (al-kutub al-fiqhiyyah) yang sebenarnya hanyalah hasil interpretasi mereka atas sebuah teks yang lebih otoritatif (al-Qur'an dan alSunnah), telah ditempatkan sedemikian rupa sehingga menyamai kedudukan teksteks otoritatif tersebut, ${ }^{30}$ Maka di zaman modern fenoma yang terjadi tidak jauh berbeda dengan era sebelumnya, bahkan lebih problematis. Beberapa pemikir zaman ini menggunakan al-Qur'an hanya sebagai "simbol" otoritas. "Kembali kepada Al-Qur'an dan Sunnah" digunakan sebagai jargon yang mengukuhkan kebenaran Tuhan. Doktrin tersebut menjadi "korpus tertutup" yang tidak bisa diutak-atik dan segala hal yang bertentangan dengan doktrin tersebut dianggap bid'ah, tidak sesuai dengan ajaran Tuhan atau bahkan bila perlu dikafirkan. $^{31}$

Menurut Khaled Abou el-Fadl, istilah puritan-Islam didasarkan pada cara pandang dan keyakinan yang absolutis dan tidak kenal kompromi. Dalam banyak hal, orientasi kelompok ini cenderung menjadi puris, dalam arti tidak toleran terhadap berbagai sudut pandang (perspektif) yang berkompetisi serta menganggap realitas pluralis hanyalah sebagai bentuk pencemaran atas kebenaran sejati. ${ }^{32}$ Di antara kelompok Islam yang bisa dikategorikan sebagai penganut puritanisme adalah aliran wahabiyyah dan salafiyyah.

a. Salafiyyah

Kelompok ini didirikan oleh para pembaharu Islam abad ke-19 seperti Muhammad Abduh (w. 1323 H), Jamal ad-Din al-Afghani (w. 1314 H), Muhammad Rasyid Ridha (w. 1354 H) dan beberapa tokoh lainnya. Beberapa pemikir bahkan menisbatkan aliran ini pada sosok Ibnu Taymiyyah (w. $728 \mathrm{H}$ ) dan muridnya Ibn Qayyim al-Jawziyyah (w. $751 \mathrm{H}$ ). Istilah salaf secara bahasa berarti pendahulu, yang dalam konteks Islam merujuk pada periode Nabi, sahabat dan tabi'in. Dalam perkembangannya, salafi (pengikut aliran salaf) memiliki arti yang lebih fleksibel dan lentur, mencakup aspek autentisitas dan keabsahan. Sebagai sebuah terminologi, salafi dimanfaatkan oleh setiap gerakan yang ingin mengklaim bahwa gerakan tersebut berakar pada autentisitas dan keabsahan Islam. Bahkan, istilah yang semula digunakan oleh kaum reformis liberal abad ke-20, juga diklaim oleh kelompok Wahhabi yang juga menyebut diri mereka sebagai kaum salafi.

Selain menisbatkan salafi pada orang atau generasi tertentu umat Islam, salafi juga bisa di lihat dari aspek metodologi berfikir yang menurut Mustafa Hilmi meliputi tiga kriteria, yaitu: ${ }^{33}$

1) Memprioritaskan nas dalam memahami masalah-masalah akidah

2) Menghindari ta'wïl tafsili

3) Mengikuti alur pemaparan alQur'an dalam berakidah.

Dengan metodologi berfikir ini seorang salafi akan mampu menjaga kemurnian Islam dari hal-hal yang berbau syirik atau hal-hal yang termasuk bid'ah. Adapun jika dilihat dari segi karakter berfikir, kelompok salafi ini kemudian terbagi menjadi dua, yaitu:

a) Salafi Literalis

Ahmad bin Hanbal adalah tokoh yang sering disebut sebagai pemuka aliran ini. Dalam pandangannya, dunia pengetahuan yang telah berkembang sedemikian rupa, terlebih filsafat, sedikit banyak telah berpengaruh pada sikap beragama umat Islam. Menurut Ibn Hanbal, pola keberagamaan umat Islam telah banyak yang menyimpang dari tata aturan yang sebenarnya sebagaimana diajarkan Nabi dan para sahabat. ${ }^{34}$

Untuk menyikapi hal tersebut, Ibn Hanbal kemudian merumuskan beberapa pedoman berfikir (manhaj al-fikr as- 
salafi), baik dalam masalah aqidah maupun hukum Islam. ${ }^{35}$ Dalam bidang fikih misalnya, Ahmad ibn Hanbal mendasarkan pemikirannya pada lima pilar, yaitu:

(a) Jika dalam suatu kasus didapatkan nash hukum yang mengatur, maka nash hukum harus didahulukan dari apapun, termasuk dari fatwa sahabat.

(b) Fatwa sahabat yang menjadi kesepakatan atau tidak ada yang menyalahinya.

(c) Pendapat salah seorang sahabat yang dianggapnya lebih dekat pada maksud alQur'an atau as-Sunnah.

(d) Apabila tidak ditemukan hadis yang sahih, maka hadis mursal dan hadis da'if dapat digunakan.

(e) Dalan kondisi dimana keempat pilar hukum di atas tidak didapati maka, ibn Hanbal akan menggunakan qiyas. Artinya, penggunaan qiyas sangat terbatas hanya pada situasi darurat. ${ }^{36}$

Berdasarkan metode berfikir di atas, beberapa ahli kemudian menyimpulkan bahwa kegigihannya mempertahankan aqidah Islam sebagaimana dipraktikkan generasi salaf memunculkan klaim bahwa penyebutan istilah salafi atau salafiyyah senantiasa dikembalikan kepada ibn Hanbal. Sisi leteralis-puritanistik ibn Hanbal dalam hal fikih tidak begitu kuat sebagaimana dalam persoalan akidah. Namun demikian, jika dibandingkan dengan pemuka-pemuka fikih lainnya, pola pemikiran ibn Hanbal memang lebih literalis. Dalam hal penggunaan qiyas, maslahah atau zari' 'ah misalnya, semua perangkat metodologi ini hanya bisa digunakan dalam kondisi darurat dan tidak boleh menyimpang dari kehendak nas.

b) Salafi Rasionalis-Reformis
Akibat dari kehancuran peradaban Islam di abad keenam hijriyyah, umat Islam banyak yang menjauh dan kurang mengenal terhadap ajaran agamanya, sehingga penyelewengan dan penyimpangan terjadi di mana-mana. Dalam kondisi yang demikian, Ibn Taymiyyah (w. 1328 M) tampil ke permukaan sebagai sosok yang tidak rela melihat kondisi tersebut dan berjuang untuk mengembalikan semangat umat Islam guna menggapai kembali kejayaan dan kemurniannya. Salah satu cara yang dilakukan Ibn Taymiyyah adalah dengan mengembalikan pemahaman agama umat Islam kepada pemahaman para as-salaf as-shalih.

Untuk mencapai usahanya tersebut Ibn Taymiyyah menyusun beberapa kerangka dasar berfikir yang diyakini sebagai kerangka teori salaf di kemudian hari. Tidak banyak yang berbeda antara kerangka Ibn Taymiyyah dan Ibn Hanbal. Hanya saja, pemberian porsi seimbang antara wahyu dan akal menjadikan pemikiran salafi yang dibawanya menjadi lebih baru dan rasional, sehingga tidak berlebihan jika Ibn Taymiyyah sering disebut sebagai pembaharu pemikiran salafi.

b. Wahabiyyah

Kelompok ini dinisbatkan pada sosok Muhammad bin Abdul Wahhab (w. 1206 H/ 1792 M). Gagasan utamanya adalah bahwa umat Islam telah melakukan kesalahan besar dengan menyimpang dari jalan Islam yang lurus, dan hanya dengan kembali kepada satusatunya agama yang benar mereka akan diterima dan mendapat ridha dari Allah. Dengan dalih pemurnian ajaran Islam Abdul Wahhab bersama pengikutnya hendak melakukan pembebasan Islam dari segala unsur yang merusak dan menggerogoti kemurnian ajaran Islam seperti, tasawuf, doktrin tawassul, rasionalisme serta beberapa praktik keagamaan yang dinilai bid'ah. ${ }^{37}$

Dalam perkembangannya, Wahhabisme memperlihatkan kebencian 
yang luar biasa terhadap semua bentuk intelektualisme, mistisisme dan sektarianisme dalam Islam. Menurut mereka, semua hal tersebut adalah bentuk inovasi menyimpang yang telah masuk ke dalam ajaran Islam. Ada pihak-pihak di luar Islam yang dengan sengaja memasukkan unsur tersebut sehingga mengaburkan ajaran Islam yang sebenarnya. Oleh karenanya, mereka selalu mencurigai segala sesuatu yang berasal dari luar Arab karena dianggap memasukkan unsur-unsur non Islam ke dalam ajaran Islam, khususnya segala hal yang datang dari daerah Persia, Turki dan Yunani. ${ }^{38}$

Untuk memurnikan Islam dari ajaran yang dapat merusaknya Wahhabi menyerukan agar umat Islam kembali mengimplementasikan perintah dan contoh (tauladan) Nabi secara literal khususnya terkait dengan praktik-praktik peribadatan. Ini adalah jalan satu-satunya untuk mendapatkan bantuan dan dukungan Tuhan serta mengembalikan umat Islam dari segala keterbelakangan dan keterhinaan. Di antara yang menyebabkan umat Islam terbelakang adalah munculnya beragam mazhab pemikiran. Menurut mereka, kemunculan mazhab-mazhab tersebut telah memecah belah umat Islam dan memperlemah ukhuwwah Islamiyyah. Untuk itu, segala bentuk pemikiran atas nama mazhab tertentu harus dilebur dalam satu agenda besar yaitu untuk memurnikan ajaran Islam. Bahkan, tidak jarang Abdul Wahhab dan para pengikutnya menyebut para ahli hukum (fuqaha') abad pertengahan maupun kontemporer sebagai "pengumbar bid'ah" dan halal darahnya. Dalam konteks ini menarik untuk dicermati bahwa Wahhabi tidak konsisten dalam mengecam para fuqaha'. Terbukti bahwa mereka dengan senang hati mengikuti pemikiran Ibnu Taymiyyah dan beberapa ulama yang sejalan dengannya. ${ }^{39}$

\section{Benang Kusut antara Teks dan Konteks}

Satu hal yang tidak dapat dipungkiri oleh siapapun adalah kenyataan bahwa perintah-perintah Tuhan (khitāa al-Syāri') selalu bertumpu pada teks (nas), sementara teks itu sendiri selalu dibantu oleh alat mediasi yaitu "bahasa". Bahasa inilah yang kemudian menjadi sumber silang pendapat di kalangan banyak orang, karena keberadaannya yang tidak lain merupakan hasil kesepakatan sebuah komunitas dan rekayasa dari budaya manusia. Sebuah kata, kalimat, atau anak kalimat sangat bergantung pada suatu sistem simbol yang tentunya membutuhkan perangkat alat bantu dari asosiasi-asosiasi, gambaran-gambaran, juga emosi pendengar.

Semua perangkat di atas tidak mungkin bersifat statis dan seragam, melainkan bisa jadi berubah dari waktu ke waktu. Dengan demikian, bahasa memiliki realitas objektif tersendiri di mana proses pemaknaannya tidak bisa ditentukan secara sepihak, baik oleh author (pengarang) maupun oleh pambaca (reader). Untuk itu, ketika seseorang atau sebuah komunitas menggunakan perantara bahasa, baik sebagai media komunikasi, dialog atau penyampai gagasan, maka secara otomatis mereka harus sadar akan keterbatasan yang melekat di dalamnya.

$$
\text { Mengingat kompleksitas }
$$

persoalan yang dihadapi oleh komunitas penentu makna, maka pemahaman terhadap teks tidak bisa dilakukan secara semena-mena oleh pihak manapun, baik oleh pihak pengarang (author) maupun oleh pembaca (reader). Pemahaman terhadap teks harus mewujud dalam sebuah interaksi hidup antara pengarang (author), teks (text) dan pembaca (reader). ${ }^{40}$ Pola seperti inilah yang kemudian menurut para ahli melahirkan apa yang disebut dengan teori hermeneutik. 
Menurut Khaled Abou el-Fadl, teori hermeneutik akan melahirkan sebuah pertanyaan akademis tentang apa atau siapa yang harus menentukan makna teks (kata) dalam sebuah penafsiran. Berdasarkan teori hermeneutik, ada tiga kemungkinan jawaban yang bisa diberikan. Pertama, ketentuan makna diberikan oleh pengarang (author) atau setidaknya oleh upaya pemahaman terhadap maksud pengarang. Secara sederhana kemungkinan ini dapat dipahami bahwa makna yang sebenarnya dari sebuah teks ditentukan oleh maksud (kehendak) pengarang menggunakan teks tersebut. Atau bisa jadi penentuan makna tersebut berasal dari upaya pambaca dalam memahami teks dari pengarang. Dengan demikian, dua sisi penentuan makna ini bisa jadi mengahasilkan pemahaman yang berbeda. ${ }^{41}$

Kemungkinan kedua berpusat pada peranan teks dalam menentukan makna dan pengakuan atas tingkat otonomi teks dalam menentukan makna. Artinya, teks diposisikan sebagai satusatunya entitas yang paling berwenang dalam menentukan makna. Dalam kasus terjadinya perbedaan pemahaman antara "pengarang" dan "pembaca", maka tugas pengarang adalah mampu menunjukkan dan menjelaskan detail bahasa yang digunakan dalam teks. Dengan demikian, pemahaman pembaca dan penyampaian maksud pengarang melalui sebuah teks tidak akan memberi sebuah kepastian. Hanya dengan melakukan pembacaan yang cermat dan teliti terhadap teks lah yang dapat menjembatani kesenjangan antara pemahaman pembaca dan maksud pengarang. ${ }^{42}$

Kemungkinan ketiga adalah memberikan penetapan makna kepada pembaca. Umumnya pembaca akan membawa serta subjektivitasnya dalam proses pembacaan yang diproyeksikan kepada kehendak pengarang dan teks. Ketika pembaca melakukan pembacaan terhadap sebuah teks, maka sangat sulit bagi dirinya untuk keluar dari pengaruh pengalaman mereka sendiri. Oleh karenanya, realitas sosial, historis, psikologis atau bahkan ideologis adalah pengalaman yang lazim melekat dalam diri pembaca dan membentuk subjektivitas bacaannya. $^{43}$ Sedemikian kuat pengaruh "pengalaman" dalam membentuk subjektifitas seorang pembaca membuat pembaca yang lain harus mampu menilai dan menguji secara kritis dinamika kekuasaan (power) yang membentuk konstruksi pemahaman seseorang.

Jika teori ini ditarik dalam konteks epistemologi fikih yang berkembang dewasa ini maka akan muncul sebuah pola relasi yang unik antara pengarang (author), pembaca (reader) dan teks (text). Sebagai author Allah telah menuangkan kehendakNya dalam bentuk wahyu yang diverbalkan menjadi teks (nas) al-Qur'an. Semua diskursus keislaman, termasuk di dalamnya fikih, selalu menjadikan alQur'an sebagai poros pijak kajiannya. Sebagai orang pertama yang melakukan interaksi dengan al-Qur'an, nabi Muhammad dipercaya sebagai pihak yang paling otoritatif dalam menentukan makna kata dalam teks-teks al-Qur'an. Hampir-hampir tidak ada jarak pemahaman antara nabi Muhammad sebagai pembaca (reader) dengan Allah sebagai pengarang (author). Sebagai pengarang, Allah senantiasa memantau hasil bacaan Muhammad dan memberikan koreksi jika ada pemahaman yang tidak sejalan dengan kehendakNya. Hal ini sesuai dengan apa yang difirmankanNya: dan tiadalah yang diucapkannya itu (al-Qur'an) menurut kemauan hawa nafsunya. Ucapannya itu tiada lain hanyalah wahyu yang diwahyukan (kepadanya). ${ }^{44}$

Setelah Muhammad, jarak antara pembaca, pengarang dan teks mulai tampak. Terlebih ketika pembaca hidup di masa di mana teks tersebut sudah lama berhenti proses penurunannya (tanzīi). Semakin kebelakang periode hidup 
pembaca, maka akan semakin jauh pula jarak antara dia dengan pengarang dan juga teksNya. Dengan demikian, menjadi hal yang sangat wajar jika kemudian terjadi perbedaan antara satu pembaca dengan pembaca yang lain dalam hal menentukan makna teks (al-Qur'an) yang dibacanya. Justeru akan menjadi tidak wajar apabila masing-masing pembaca kemudian memaksakan hasil bacaannya kepada orang lain dan mengklaim diri sebagai bacaan yang paling otoritatif. Sebab, walau bagaimanapun subjektifitas pembaca menjadi hal yang sulit dihindari, terlebih dalam konteks zaman dimana kompleksitas kehidupan semakin meningkat. Terkait dengan hal ini, Ibn Rusyd pernah mengingatkan bahwa persoalan (kasus) yang dihadapi umat manusia tidak pernah mengenal kata berhenti, sementara teks-teks keagamaan sudah paripurna. Oleh karenanya, mengatasi persoalan yang tidak pernah berhenti dengan sesuatu yang sudah paripurna menjadi hal yang tidak mudah dilakukan. Apalagi mencoba menyatukan semua pandangan untuk menghasilkan satu solusi yang sama. ${ }^{45}$

Sangat sulit untuk mengatakan bahwa satu paradigma adalah lebih otoritatif dan objektif dibanding yang lain atau sebaliknya. Atas dasar ini pulalah Khaled mansyaratkan adanya lima pondasi agar sebuah pemahaman dapat dipercaya dan dipertanggungjawabkan, yaitu:

1. Kejujuran $^{46}$

2. Kesungguhan ${ }^{47}$

3. Kemenyeluruhan. ${ }^{48}$

4. Rasionalitas ${ }^{49}$

5. Pengendalian diri ${ }^{50}$

Berdasarkan kelima pondasi di atas, maka setiap pradigma fikih yang berkembang bisa dilihat tingkat validitas dan keterpercayaannya dalam menentukan makna dari sebuah perintah Tuhan. Namun demikian, mengingat bahwa kelimanya lebih bersifat moralindividual (pribadi) sementara fikih selalu berkembang mengiringi berbagai entitas di luarnya yang juga selalu berubah, ${ }^{51}$ maka pemahaman yang paling ideal adalah bersifat integratif. Artinya, kualitas moral pembaca atau konseptor, harus dilihat secara adil dengan mempertimbangkan aspek sosio-historis dan sosio-sosio politis yang melingkupinya.

\section{Penutup}

Perkembangan

diskursus

keislaman, khususnya fikih, telah melahirkan banyak sekali mazhab atau aliran pemikiran. Dalam konteks sekarang, wajah pemikiran Islam setidaknya terbagi kedalam dua corak: inklusif dan eksklusif atau moderat dan puritan. Kelompok inklusif dalam perkembangannya juga bermetamorfosa menjadi utilitarianisme dan liberal. Sementara kelompok puritan pada akhirnya juga berkembang menjadi salafi dan wahhabi. Karena pertimbangan bahwa perbedaan antara kelompok salafiwahabi tidak begitu signifikan, maka secara umum peta pemikiran Islam (fikih) kontemporer didominasi oleh mazhab Utilitiranisme-moderat (mayoritas), liberal dan eksklusif-puritan.

Secara epistemologis, rancang bangun pemikiran ketiga mazhab tersebut memiliki banyak perbedaan. Epistemologi mazhab Utilitrianismemoderat dibangun atas pilar-pilar metodologi keilmuan yang sudah mapan sebelumnya. Dengan kata lain, mazhab ini hanya mengembangkan epistemologi yang dikembangkan oleh ulama' populer era keemasan fikih, khususnya bagaimana agar fikih mampu menjamin kemaslahatan umat Islam di kehidupan modern. Atas dasar itu pula, kelompok ini kemudian mengembangkan teori maslahah dan maqasid as-syari'ah sedemikian rupa agar mampu menjawab persoalan kekinian umat Islam.

Apa yang dilakukan oleh mazhab ini, oleh kelompok liberal dianggap belum cukup untuk mengatasi problem kekinian umat Islam. Hal ini lebih terasa 
ketika umat Islam harus berhadapan dengan fenomena modernitas yang melanda hampir seluruh aspek dalam kehidupan manusia. Dalam kondisi seperti ini, mereka beranggapan bahwa hukum Islam yang dikembangkan melalui metode usul fikih yang sudah ada terlihat pongah dan gagap ketika harus berhadapan dengan laju peradaban modern.

Meskipun

sama-sama

mengedepankan inklusivitas, kelompok liberal lebih berani keluar dari metodologi mainstream yang dikembangkan oleh ulama'. Bahkan mereka juga menawarkan dan mengembangkan metodologi baru dalam diskursus hukum Islam, yang dalam banyak hal, tidak memiliki pijakan sama sekali dalam tradisi pemikiran hukum Islam.

Adapun kelompok eksklusif-
puritan, mengembangkan apa yang
mereka sebut dengan "semangan

\section{Catatan Akhir:}

1 Abdullah Saeed, Interpreting the Qur'an: Toward Contemporary Approach (New York: Routledge, 2006), hlm. 2.

2 Al-Malā 'A $\bar{i}$ al-Qāri, "Al-Asrār alMarfū'ah fi al-Akhbār al-Maudū'ah”, dalam $C D$ Program Jawāmi' al-Kalim, kata kunci “ummatī rahmatun".

${ }^{3}$ CD Maktabah Syamilah, kata kunci "yahtamil al-Ṣawāb". Lihat juga Lihat Yayan Sopyan, Tarikh Tasyri': Sejarah Pembentukan Hukum Islam (Depok: Gramata Publishing, 2010).

${ }^{4} \mathrm{Hal}$ ini bisa dilihat misalnya pada krisis politik yang terjadi antara kelompok Ali ibn Abi Thalib dan Mu'awiyah ibn Abi Sufyan yang kemudian melahirkan sekte-sekte teologi (kalam) Islam seperti Khawarij, Syi'ah, Mu'tazilah, Qadariyah, Jabbariyyah, Ahlus Sunnah wal Jama'ah dan lain sebagainya. Tidak jarang dari semua sekte ini saling mengkafirkan satu sama lain dan menggunakan kekerasan dalam mempertahankan argumennya serta melemahkan argumen kelompok lain. Lihat harus Nasution, Teologi Islam (Jakarta: UI Press, 2009).

${ }^{5}$ Lihat Aॉi Hasaballāh, Ușūl al-Tasyrī' al-Islāmīi (Mesir: Dār al-Ma'ārif, t.th), hlm. 3-5.

6 Lihat Huzaimah Tahido Yanggo, Pengantar Perbandingan Mazhab (Jakarta: pemurnian Islam." Dalam konteks ini, tidak ada epistemologi apapun yang bisa dikembangkan untuk m9embangun Islam, kecuali hanya kembali kepada al-Qur'an dan as-Sunnah. Artinya, mazhab ini mengembangkan sebuah epistemologi tekstual dan mengesampingkan segala bentuk pemahaman kontekstual yang banyak bertumpu pada penggunaan nalar.

Berdasarkan kesimpulan di atas, dapat dipahami pula bahwa modernisme atau postmodernisme membawa dampak yang signifikan terhadap perkembangan pemikiran hukum Islam. Paling tidak, munculnya tiga mazhab fikih di atas menegaskan bahwa antara hukum Islam dengan realitas sosial tidak pernah berhenti untuk saling berdialektika. Poin inilah yang sebenarnya harus digarisbawahi dalam upaya membangun sikap terbuka dan toleran dalam beragama, khususnya di era dimana keragaman sudah menjadi hal yang tidak terelakkan lagi.

Logos, 2003), hlm. 73-74. Lihat juga Mannā', Khalil al-Qațān, Tärikh Tasyrī' al-Isläm $\bar{i}$ (Riyādh: Maktabatul Ma’ārif, 1996), hlm. 289.

${ }^{7}$ Nasr Hamid Abu Zayd, Imam Syafi' $i$ : Moderatisme, Eklektisisme. Arabisme, terj. Khairan Nahdhiyin (Jogjakarta: LkiS, 2012), hlm. 3-8.

${ }^{8}$ Tentang kiprah ketiga tokoh ini bisa dilihat pada Oliver Roy, Gagalnya Islam Politik, alihbahasa Harimurti dan Qomarudin SF (Jakarta: Serambi, t.t).

9 Lihat Syeikh Idahram, Sejarah Berdarah Sekte Salafi Wahabi (Jogjakarta: Pustaka Pesantren, 2011).

${ }^{10}$ Beberapa karya usul fikih era ini yang berhasil penulis lacak antara lain: Ușūl al-Fiqh karya Abdul Wahhāb Khallāf, Ușūl al-Fiqh alIslämì karya Wahbah al-Zuhaili, Ușūl al-Tasyri ${ }^{\prime}$ al-Islāmì karya Ali Hasaballāh, Dawābit alMaṣlahah karya Sa'id Ramaḍān al-Būthì dan masih banyak lagi lainnya. Adapun kitab-kitab fikih yang bisa disebutkan antara lain: al-Isläm: Aqīdah wa al-Syari'ah karya Mahmūd Syaltūt, al-Fiqh al-Islämi wa Adillatuh karya Wahbah alZuhayli, Fiqh al-Mar'ah dan Fiqh al-Zakah karya al-Qarḍawi dan lain-lain.

${ }^{11}$ Ibid., hlm. 8.

${ }^{12}$ Lihat Amin Abdullah, "Al-Ta'wil al'Ilmi: Kearah Perubahan Paradigma Penafsiran 
Kitab Suci," dalam Al-Jami'ah, Vol.39, 2001, hlm. 359-391.

13 Uraian lebih lanjut mengenai pergeseran paradigma ini bisa dibaca pada Thomas Kuhn, The Stucture of Scientific Revolutions (Chicago: The University of Chicago Press, 1970).

${ }^{14}$ Lihat Wael b. Hallaq, A History of Islamic Legal Theories: An Introduction to Sunni Usul Fiqh (Cambridge: Cambridge University Press, 1987).

${ }^{15}$ Ibid., hlm. 214.

${ }^{16}$ Amin Abdullah, "Paradigma Alternatif Pengembangan Ushul Fikih dan Dampaknya pada Fikih Kontemporer", dalam Ainurrifiq, Mazhab Jogja (Jogjakarta: ar-Ruzz, 2002), hlm. 118-123.

${ }^{17}$ Rahman telah menyadari kemungkinan bahaya subyektifitas penafsir, untuk menghindarkan atau setidaknya untuk meminimalkan bahaya subyektifitas tersebut rahman mengajukan sebuah metodologi tafsir yang terdiri dari tiga pendekatan: Pertama, pendekatan historis untuk menemukan makna teks; kedua, pendekatan kontekstual untuk menemukan sasaran dan tujuan yang terkandung dalam ungkapan legal spesifik dan ketiga, pendekatan latar belakang sosiologis untuk menguatkan hasil temuan penedekatan kontekstual atau untuk menemukan sasaran dan tujuan yang tidak dapat diungkapkan oleh pendekatan kontekstual. Lihat ibid., hlm. 134135.

${ }^{18}$ Fazlurrahman, Membuka Pintu Ijtihad, terj. Anas Mahyyudin (Bandung: Pustaka, 1984), hlm. 278-279.

19 Fazlurrahman, Islam and Modernity: Transformation of an Intellectual Tradition (Chicago: The University of Chicago Press, 1982), hlm. 5.

20 Moh. Dahlan, Abdullah Ahmed anNa'im: Epistemologi Hukum Islam (Yogyakarta: Pustaka Pelajar, 2009), hlm. 164.

21 Abdullah Ahmed An-Naim, Dekontruksi Syari'ah: Wacana Kebebasan Sipil, HAM dan, Hubungan Internasional, alihbahasa Ahmad Suaedy dan Amiruddin ar-Rany ( Yogyakarta: LKiS, 1990).

${ }^{22}$ M. In'am Esha, "Muhammad Syahrur: Teori Batas," dalam Khudlori Soleh dkk, Pemikiran Islam Kontemporer (Yogyakarta : Jendela, 2003), hlm. 296

${ }^{23}$ Muhammad Syahrur, Al-Kitab wa alQur'an: Qira'ah Mu'asirah, cet.2 (Damaskus: Dar al-Ahali, 1990), hlm. 42-43.

${ }^{24}$ Ibid.

${ }^{25}$ Secara umum, teori batas (Nazariyyah al-Hudūd) barangkali dapat digambarkan bahwa terdapat ketentuan Tuhan yang diungkapkan dalam al-Qur'an dan Sunnah yang mentapkan batas bawah yang merupakan batas minimal ayng dituntut oleh hukum dan batas atas merupakan batas maksimal bagi seluruh perbuatan manusia. Yang jika melanggar batas minimal dan maksimal tersebut dianggap perbuatan yang dilarang (haram)dengan kata lain manusia bisa melakukan gerak dinamis dalam batas-batas yang telah ditentukan. Amin Abdullah, Paradigma Alternatif., hlm. 134-135

26 Metodologi yang digunakan syahrur adalah filsafat dengan titik berat pada filsafat materialisme. Hal ini terlihat pada pandangannya bahwa sumber pengetahuan yang hakiki adalah alam materi diluar diri manusia. Adapun pendekatan yang digunakan adalah pendekatan hermeunetik dengan penekanan pada asfek filologi dan ini tercermin jelas pada seluruh bagian pembahasannya. Adapun kerangka teoritik yang menjadi acuan Syahrur dalam memformulasikan ide-idenya dalam ajaran islam membedakan antara yang berdimensi nubuwah yang merupakan kumpulan informasi kesejarahan yang dengan itu dapat dibedakan antara benar dan salah dalam relitas empirisnya dan risalah adalah kumpulan ajaran yang wajib dipatuhi oleh manusia yang berupa ibadah, muamalah, akhlak dan hukum halal-haram. Ibid., hlm. 136-138.

${ }^{27}$ Muhammad Salman Ghanim, Kritik Ortodoksi: Tafsir Ayat Ibadah, Politik, dan Feminisme, (Yogyakarta: LKiS, 2004), hlm. viii. Lihat juga Nurcholish Madjid dkk, Fiqh Lintas Agama: Membangun Masyarakat InklusifPluralis (Jakarta: Paramadina, 2004), hlm. 135; Zuhairi Misrawi dkk, Islam Negara dan Civil Society: Gerakan dan Pemikiran Islam Kontemporer, (Jakarta: Paramadina, 2005), hlm. 282-300.

${ }^{28}$ Khaled Abou El Fadl, Selamatkan Islam dari Muslim Puritan, terj. Hilmi Mustofa (Jakarta: Serambi, 2006), hlm. 139.

${ }^{29}$ Ibid.

${ }^{30}$ Sahal Mahfudz, Nuansa Fiqh Sosial, (Yogyakarta: LKiS, 1994), hlm. 21.

31 Nurcholish Madjid dkk, Fiqh Lintas Agama (Jakarta: Paramadina, 2005), hlm. 133.

32 Khaled Abou el-Fadl, Selamatkan, hlm. 29

${ }^{33}$ Mustafā Hilmì, Qawāid al-Manhaj alSalafi, cet. 2 (Iskandariah: Dār ad-Da'wah, 1991), hlm. 209.

${ }^{34}$ Andi Aderus, Karakteristik Pemikiran Salafi (Jakarta: Kementrian Agama RI, 2011), hlm. 114.

35 Hasbie as-Shiddieqy, Pokok-pokok Pegangan Imam Mazhab (Semarang: Pustaka Rizki Putera, 1997), hlm. 533

${ }^{36}$ Ibid., hlm. 274-275.

${ }^{37}$ Ibid., hlm. 61.

${ }^{38}$ Ibid., hlm. 63. 
${ }^{39}$ Ibid., hlm. 63.

40 Amin Abdullah, "Pendekatan Hermeneutik dalam Studi Fatwa-fatwa Keagamaan", dalam Khaled M. Abou el-Fadl, Atas Nama Tuhan, terj. R. Cecep Luqman Yasin (Jakarta: Serambi, 2004), hlm. XI-XII.

${ }^{41}$ Ibid., hlm. 183.

${ }^{42}$ Ibid., hlm. 184.

${ }^{43}$ Ibid., hlm. 184-185.

${ }^{44}$ Q.S An-Najm (53): 3-4.

45 Abū al-Walid Muhammad ibn Rusyd al-Hafid, Bidāyah al-Mujtahid wa Nihāyah alMuqtasid (Indonesia: Dār Ihya' al-Kutub alArabiyyah, t.t), hlm. 2. Lihat juga Wael B. Hallaq, "Membaca Teori Batas Muhammad Syahrur", dalam Muhammad Syahrur, Prinsip dan Dasar Hermeneutika Hukum Islam Kontemporer, terj. Sahiron Syamsudin dan Burhanudin Dzikri (Jogjakarta: ELSAQ Press, 2007), hlm. 15.

${ }^{46}$ Khaled M. Abou el-Fadl, Atas Nama Tuhan, hlm. 100.

${ }^{47}$ Ibid., hlm. 100-101.

${ }^{48}$ Ibid., hlm. 101

${ }^{49}$ Ibid., hlm. 102

${ }^{50}$ Ibid., hlm. 102-103.

51 Lihat NJ Coulson, Konflik dalam Jurisprudensi Islam, terj. Fuad Zein (Jogjakarta: Navila, 2001).

\section{DAFTAR PUSTAKA}

Abdullah Amin. “Al-Ta'wil al-'Ilmi: Kearah Perubahan Paradigma Penafsiran Kitab Suci", dalam AlJami'ah, Vol. 39, 2001.

Aderus, Andi. Karakteristik Pemikiran Salafi. Jakarta: Kementrian Agama RI, 2011.

Al-Hafid, Abū al-Walid Muhammad ibn Rusyd. Bidāyah al-Mujtahid wa Nihâyah al-Muqtasid. Indonesia: Dār Ihya' al-Kutub al-Arabiyyah, t.th.

Al-Qatțān, Mannā' Khaliil. Tärikh Tasyrí, al-Islāmī. Riyādh: Maktabatul Ma'ārif, 1996.

Asymāwi, Muhammad Saīd. Ușūl alSyarī'ah. Beirut: Dar Iqra' 1983.

Coulson, Lihat NJ. Konflik dalam Jurisprudensi Islam. alihbahasa Fuad Zein. Jogjakarta: Navila, 2001.
Dahlan, Moh. Abdullah Ahmed anNa'im: Epistemologi Hukum Islam. Yogyakarta : Pustaka Pelajar, 2009.

El Fadl, Khaled Abou. Selamatkan Islam dari Muslim Puritan, terj. Hilmi Mustofa. Jakarta: Serambi, 2006.

Esha, M. In'am. "Muhammad Syahrur: Teori Batas." dalam Khudlori Soleh dkk, Pemikiran Islam Kontemporer. Yogyakarta : Jendela, 2003.

Ghanim, Muhammad Salman Kritik Ortodoksi: Tafsir Ayat Ibadah, Politik, dan Feminisme. Yogyakarta: LKiS, 2004.

Hallaq, Wael b. A History of Islamic Legal Theories: An Introduction to Sunni Ushul Fiqh. Cambridge: Cambridge University Press, 1987.

Hasaballāh, Ađi. Ușūl al-Tasyrì' alIslāmì. Mesir: Dār al-Ma'ārif, t.th.

Hilmī, Musțafā. Qawāid al-Manhaj asSalafi. Iskandariah: Dār alDa'wah, 1991.

Idahram, Syeikh. Sejarah Berdarah Sekte Salafi Wahabi. Jogjakarta: Pustaka Pesantren, 2011.

Iqbal, M. The Reconstruction of Religious Thought in Islam. Lahore: Ashraf Press, 1971.

Kuhn, Thomas. The Stucture of Scientific Revolutions. Chicago: The University of Chicago Press, 1970.

Madjid, Nurcholish. dkk. Fiqh Lintas Agama: Membangun Masyarakat Inklusif-Pluralis. Jakarta: Paramadina, 2004.

Mahfudz, Sahal. Nuansa Fiqh Sosial. Yogyakarta: LKiS, 1994.

Misrawi, Zuhairi, dkk. Islam Negara dan Civil Society, Gerakan dan Pemikiran Islam Kontemporer. Jakarta: Paramadina, 2005.

Al-Na'im, Abdullahi Ahmed. Dekonstruksi Syari'ah. Jogjakarta: LKiS, 2003. 
Toward an Islamic Reformation: Civil Liberties, Human Right and International Law. Syiracuse: Syiracuse University Press, 1990. The Second Message of Islam. Syiracuse: Syiracuse University Press, 1987.

Nasution, Harun. Teologi Islam. Jakarta: UI Press, 2009.

Rahman, Fazlur. Islam and Modernity: Transformation of an Intellectual Tradition. Chicago: The University of Chicago Press, 1982.

. Membuka Pintu Ijtihad, terj. Anas Mahyyudin. Bandung: Pustaka, 1984.

Roy, Oliver. Gagalnya Islam Politik. alihbahasa Harimurti dan Qomarudin SF. Jakarta: Serambi, t.th.

Saeed, Abdullah. Interpreting the Qur'an: Toward Contemporary Approach. New York: Routledge, 2006.
Al-Ṣābūnì, Abū Usāmah Ismā'ìl bin Abdurrahmān. Aqidah as-Salaf. Kairo: Al-Kurdy, $1325 \mathrm{H}$.

Sopyan, Yayan. Tarikh Tasyri': Sejarah Pembentukan Hukum Islam. Depok: Gramata Publishing, 2010.

Syahrūr, Muhammad. Al-Kitāb wa alQur'ān: Qirā'ah Mu'āsirah. Damaskus: al-Ahāli al-Tibā'ah li al-Nasyr wa al-Tauzi', 1992. - Prinsip dan Dasar Hermeneutika Hukum Islam Kontemporer. alihabahasa Sahiron Syamsudin dan Burhanudin Dzikri. Jogjakarta: ELSAQ Press, 2007.

Yanggo, Huzaimah Tahido. Pengantar Perbandingan Mazhab. Jakarta: Logos, 2003.

Zayd, Nasr Hamid Abu. Imam Syafi'i: Moderatisme, Eklektisisme. Arabisme. alih bahasa Khairan Nahdhiyin. Jogjakarta: LkiS, 2012. 